\title{
Municipal Websites in the Local Public Debate
}

\author{
Supplying Facts or Setting Agenda?
}

\author{
Marte Winsvold
}

\begin{abstract}
The proliferation of digital communication spaces is expected to have the paradoxical effect of both enhancing pluralism as well as causing a fragmentation of the public political debate. The question addressed in this paper concerns the position of one such space of communication in the local public debate - municipal websites. Four Norwegian municipalities are studied, and the role of their websites is assessed by evaluating the visibility and the extent to which the contents of these websites affect the agenda of the local media. The study indicates that even though the municipal websites are not particularly visible to the citizens, they still influence the public political agenda by being a source of information to the press. As the communication taking place on the municipal websites spills over to the media and thereby reaches the majority of the citizens, the websites can not be said to lead to a fragmentation of the public debate. Whether or not the websites contribute to the pluralism of the public debate is however uncertain. ${ }^{1}$
\end{abstract}

Key Words: municipal websites, public debate, local politics, Internet, agenda setting, local media

\section{Introduction}

During the last ten years most Norwegians municipalities have established official websites. These websites are taking on many of the functions of the traditional local press, such as providing political information, publishing news and offering arenas of public debate. The question addressed in this paper concerns the role of these websites compared to the traditional media, in the public political communication arena in the municipalities.

The potential of the Internet as an arena for political communication has been discussed in a number of articles (e.g. Poster 1995, Papacharissi 2002, Hoff \& Storgaard 2005, Nygren 2005, Torpe 2005). Internet's technological features and specifically those related to the opportunity for the widespread dissemination of information from several sources have lead to expectations of a more informed and pluralist public debate. Conversely, sceptics caution that the multitiude of digital communication arenas addressing different segments of the population may lead to a fragmentation of the public debate (Liestøl \& Rasmussen 2003, Polat 2005). Empirical studies of the Internet's contribution to the public political communication have so far focused mainly on the question 
of digital inclusion, the emergence of alternative public spheres and on the quality of the dialogues taking place in diverse Internet forums (e.g. Fung 2002, Jensen 2003, Papacharissi 2004, Fuller 2004, Janssen and Kies 2005, Ulrich 2005). Few studies however, have looked at how digital communication arenas such as municipal websites are actually connected to, and integrated into, the wider political debate (Dahlberg 2004). The aim of this article is therefore to explore the position and integration of municipal websites in the local public debate. To what extent and in what ways do the municipal websites contribute to the local public debate? Do contents published on the websites enter into and influence the public debate, or are they invisible and unimportant to the public communication of the municipality? And do the existence and use of the municipal websites lead to a widening or to a fragmentation of the public debate?

Initially, the democratic function of the public debate is discussed. Following this discussion, two criteria are proposed - visiblity and agenda influence - that are subsequently used to evaluate the position of the municipal websites in the public debate.

\section{Public Debate - Taking Place in the Public Sphere}

The public discourse of issues concerning the community has an important function in the democratic process although the role attributed to it varies across different democracy models. According to a deliberative democracy model, the citizens should set the political agenda, identify solutions and validate the opinions and decisions of the political elite through public discussions. The participation of the public in the debate is as an interactive audience in assessing the validity of the different opinions and arguments and thereby urging the political participants to be rational and sober in their presentations (Habermas 1996, Eriksen \& Weigård 2003). In more aggregative and elitist democracy models where citizens primarily participate in the political process by casting their ballot, the function of the political debate is to give the citizens information on the opinions, values and political achievements of different political candidates, and thereby helping them to choose who to vote for (March \& Olsen 1989, Kjeldsen 1998, Mouffe 1999). Common to the different views on the public debate however, is the constitutive role of the audience; the arguments in the public debate are more or less aimed at the audience. A debate will not be public without an audience, and a public debate consequently consists both of those actively participating and of those listening.

When describing the nature of public debates the focus is often on two-way argumentation either with immediate responses such as in television debates, or with delayed responses such as in debates in newspapers. I will argue, leaning on the description of the changed role of the public sphere, proposed by John B. Thompson (1995), that the modern political debate consists both of direct and two-way communication and of oneway argumentation, often in the form of information. According to Thompson the public debate changed character with the emergence of the mass media, the debate being separated from the dialogical exchange that characterized the physical contact in the public sphere in pre-modern times. The relationship between senders and receivers became a relationship of quasi-interaction, of monologue. Consequently, the constitutive element of the modern debate in the public sphere became, not the interaction, but the visibility of opinions and arguments (Thompson 1995, Janssen \& Kies 2005). The one-way argumentation dominant in modern mass media must therefore be perceived as part of a discussion which extends in time and space, where counter-arguments or reactions may occur in another medium, with a delay in time and not necessarily directly aimed at one 
specific or identifiable statement. As members of the audience, the citizens observe and interpret this one-way argumentation as part of an ongoing discussion.

According to Jürgen Habermas and his critiques, the public sphere consists of a complex network of various public sphere segments (Fraser 1992, Habermas 1996, Hoff \& Storgaard 2005). These different sub-spheres are interconnected and porous to one another, meaning that a text appearing in one segment of the public sphere in some way may extend into the other sub-spheres, and it will always be possible to "build hermeneutical bridges from one text to the next" (Habermas 1996:374). The constellation of sub-spheres will thus constitute one plural, but still coherent public sphere. In the same way, the public debate about a specific subject, taking place in the public sphere, will also constitute one plural, but coherent debate. Following this argument, the public debate on a specific subject may comprise a large number of discussions taking place in different arenas, involving different participants and activating different segments of the public audience. The question is whether or not the different debates about one specific subject can still be characterized as one debate. I will argue that for a debate to be public it must in some way be connected to the other publicly visible debates on the same subject. If it is not, the stated arguments and points of view would not reach outside the specific setting where they occur, which means they would be isolated from the wider public debate and must be regarded as belonging to an exclusive compartment of the debate, essentially private. The interconnectedness of the different debate arenas is a prerequisite for a pluralist debate, as pluralism requires that the same group of people receive information from diffent sources, thereby bringing different perspectives into the debate. If the different arenas of communication are knit together hosting one coherent debate, this indicates the same audience perceives different perspectives. Conversely, if different segments of the population are exposed to separate perspectives and arguments, being differently informed, the debate is not pluralistic, but fragmentized, meaning there is not one, but several independent and isolated debates. The municipal website may constitute a public segment in a network of sub-spheres, enhancing the pluralism of the public debate or it may constitute an isolated segment, unconnected to the other sub-spheres, indicating a fragmentation.

Based on the discussion above, two criteria to evaluate the position of municipal websites in the public debate are proposed. First, if the content of the municipal website is to be part of the public debate, there must be an audience; someone must be reading or listening to what is uttered - hence, the criterion of visibility (Thompson 1995, Hoff \& Storgaard 2005). Secondly, for the communication of a municipal website to be an influential element of the wider public debate it must be connected to the debate that is taking place in other public spaces. This means there must be a spill-over of content from the municipal website to other arenas and the content of the debate in other arenas must in some way be affected. This will be called the criterion of agenda influence. By public agenda, I refer to the agenda of the media. The public agenda also consists of the issue priorities of the citizens and the agenda of the politicians (Kosicki 1993), but as the focus here is on communication taking place in public arenas, I will concentrate on the agenda of the media.

The visibility of a municipal website will be assessed by the use of two indicators; who visits it and how its importance is evaluated by the audience. The agenda influence of the website will be assessed by looking at the degree of spill-over of content and at how the agenda influence is evaluated by stakeholders often regarded as having influence on the public agenda; namely journalists and politicians. Both visibility and agenda 
influence will indicate that the communication is included in the public debate and may thereby contribute to the pluralism of the debate. Conversely, scarce or partial visibility will indicate the website is not public, and lack of spill-over and agenda influence will indicate fragmentation. As illustrated by Figure 1 both criteria affect the position of the municipal website in the public debate.

Figure 1. Criteria for Evaluating Position in the Public Debate

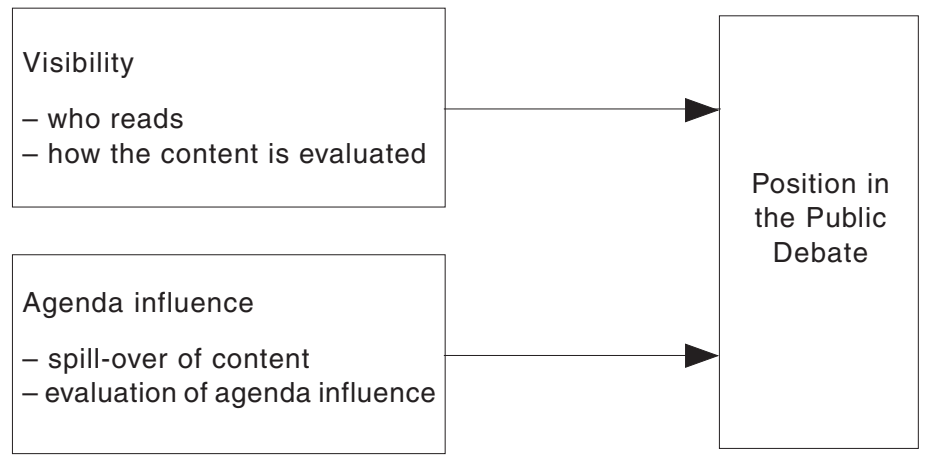

\section{Data and Research Method}

To explore the role of municipal websites in the local public debate I will draw on data gathered in four Norwegian municipalities: Drammen, Troms $\varnothing$, Stavanger and Førde. These municipalities are chosen because they have well developed municipal websites as well as several other arenas of public debate with which the municipal websites may interfere. In addition to regular council meetings, all four municipalities organize either regular or occasional public meetings where citizens can discuss issues with each other and with local politicians. Furthermore, every municipality has at least one local printed newspaper, and two of the municipalities, Troms $\varnothing$ and Stavanger, have two competing newspapers. The newspapers also cover the surrounding areas, but the editorial offices are situated in the municipalities, and the larger part of the contents is dedicated to issues from the case municipalities. The municipalities also have one or more local radio stations and one or more local television channels. Finally, all the municipalities have web versions of local newspapers.

The municipalities vary in size from Førde with about ten thousand inhabitants to Drammen and Troms $\varnothing$ with nearly sixty thousand and Stavanger with a little over a hundred thousand inhabitants, and they are situated in different parts of Norway; Førde and Stavanger in the west, Troms $\emptyset$ in the north and Drammen in the east. The municipalities are not representative for the totality of Norwegian municipalities, but as they differ in size and geographical location, findings consistent across them can be considered fairly strong, and may indicate more general tendencies. Variations between municipalities will tentatively be explained by reference to differences between them.

To study the position of the municipal websites in the local public debate, a multimethodological approach has been applied, including in-depth interviews, surveys and content analysis. 
Interviews: In order to give an indication of the visibility and agenda influence of the municipal websites, interviews were conducted with about ten municipal councillors in each municipality, as well as all members of the information department in each municipality, representatives of the local media, namely the editor and one or two political journalists in the local newspapers and also the web editor of the local newspapers. The interviewed politicians were selected on the basis of two criteria; they regularly and vocally participated in the public debate and the information department in the municipality recommended them as being fairly skilled in using information and communication technology. As the major elements of the research question were ICT and the public debate it was important to interview those who had experience of both of them. The interviewed politicians are therefore not representative of all politicians. To correct this bias, a survey covering many of the same questions was sent to all the elected representatives in the four case municipalities. As for the journalists; those who were mainly responsibility for covering local politics in the municipality were selected. A total of nine representatives from the press were interviewed. The interviews were carried out between September 2004 and September 2005.

Surveys: In order to give an indication about the use and thus the visibility of the website, two questionnaire surveys were conducted; the first in April 2005 among all municipal councillors and the second of the general public in October 2005. The public survey questionnaire was sent out by mail to a randomly selected sample of 3600 inhabitants in the four municipalities. To enhance the response rate, those who returned the completed forms could win a travel voucher, and a written reminder was sent after three weeks. In spite of this, the average response rate was not higher than 35 percent, varying slightly between the municipalities, from 36 per cent in Stavanger and Førde, to 35 percent in Troms $\varnothing$ and 31 percent in Drammen. A total of 1275 persons responded to the survey. Analysis of the data indicates that the most politically active part of the population is overrepresented in the survey. Compared to data gathered in official national surveys with a higher response rate, the bias of the present sample does not however appear to be very large. ${ }^{2}$ Respondents under 30 years old are underrepresented, and the data are weighted for age in proportion to the age distribution in the population. The reported frequencies must in any case be interpreted with caution, as they may overestimate the overall local political activity. When possible, the frequencies are compared to similar frequencies from national surveys. Interpreting results from multivariate analysis are less problematic since political activity, as well as socio-demographic biases in the sample, is then controlled. A reason for the low response rate may be that the number of population surveys has increased substantially during the last decade, causing a general fatigue in the population. A decline in the proportion responding has been observed in comparable surveys (Statistics Norway, Research and Analysis 2006).

In the politicians' survey 100 of 186 politicians responded, which gives a response rate of 54 per cent. There is no indication of the nature of the bias in this sample, but these results must also be analyzed with caution.

Content analysis: Spill-over of contents from the municipal website to the media could, as argued above, indicate that the websites have a certain influence on the agenda of the media. To trace such spill-over, a content analysis of the four municipal websites and of one newspaper from each municipality was conducted. In municipalities with two newspapers, the one with the largest circulation was chosen. In each municipality, the contents of the municipal website were systematically compared to the contents of the 
local newspaper during a period of three weeks in January 2005 ( $11^{\text {th }}$ to the $\left.31^{\text {st }}\right)$. Contributions were classified as incidents of spill-over when texts were clearly copied from the municipal websites, that is, when a text exclusively published on the municipal website subsequently appeared in identical form in the newspaper. Contributions were also classified as incidents of spill-over if the content of the newspaper article could be traced back to the contents exclusively published on the websites, for example from news items produced by the information department of the municipality or background documents distributed and publicized by the municipality via the web. Lastly, newspaper-articles that actively referred to contents from the municipal website were classified as incidents of spill-over.

\section{What is the Position of the Municipal Websites in the Local Public Debate?}

Contents regarding both public services and politics were published on the municipal websites. Political content occured in news presented on the front page as well as in a distinct section named "politics". The bulk of the political communication on the municipal websites is best characterized as one-way information, including news, protocols, meeting agendas and mail journals. Three out of four websites also offered possibilities for interactive communication via consultation or discussion forums at the time the data were collected. ${ }^{3}$ As for the news items, they did in one way or another have to do with the responsibilities of the municipality; either political decisions or municipal services. The municipality of Førde also announced cultural events and searched for employees through the website. The interval of updates varied across the municipalities. The most frequently updated website was that of Drammen, posting on average 1.8 news items a day during the three-week period. Drammen compared favourably with Førde (1.4), Stavanger (0.9) and Troms $\emptyset$ (0.6).

The genre of the contents published on the websites differs. Mail journals, meeting agendas and summaries have a highly factual and neutral style. The background documents are more elaborate and may not be that neutral, but as the documents are usually signed, the content can be interpreted with reference to the author. The genre of the news published on the front page resembles the news genre of the local press in that the articles have a heading, an introduction and a following text presenting a specific issue. The news items also often has a dramaturgic composition making them resemble stories and not mere facts and indicating that the they have undergone strategic considerations concerning what to present and what to omit. Nevertheless, they are often presented as pure information, and they are often unsigned. The news on the website consequently belongs to a grey zone between neutral and strategic information.

I have, up to this point, presumed that the municipal websites can contribute to a more pluralist debate by bringing alternative information to the public, thereby implying that the information published on the municipal websites differs substantially from that provided by the media. To what extent and in what manner the contents actually differ from the contents of the media, will not be studied here. It is simply taken that the information is alternative as news items on the websites are written by individuals with an institutional basis different from that of the media, making it likely that they present a different viewpoint. Also, complete background documents that are not published elsewhere are available on the municipal websites. 


\section{Visibility}

The visibility of the municipal websites in the public debate is measured by the numbers of citizens visiting the website and by their evaluation of it. A precondition for visibility is however that the public have access to the content published on the websites, which requires that they both have access to and actually use the Internet. In the four municipalities, 83 percent of the population has access to Internet, whereas 76 percent of the population uses it, 71 percent weekly or more often. ${ }^{4}$ This means that in principle the municipal websites can be visible to the majority of the public in the four municipalities. These figures are representative when compared to the access and use of the Internet by the total Norwegian population (TNS Gallup 2006). ${ }^{5}$ Lower access to and use of the Internet is associated with advanced age, a lower level of education and low income. ${ }^{6}$ These systematic biases have been established in several previous studies (Norris 2001, Hoff \& Storgaard 2005), but are decreasing as Internet access becomes more widespread (Tobiassen 2005). When compared to access and use of other arenas of public debate, access to and use of the Internet is, however, consistently lower. Nearly 100 percent of the population have access to television and radio in their homes (Statistics Norway 2006) and in the four municipalities about 90 percent read the local newspaper at least once a week ${ }^{7}$, a number also representative for the Norwegian population (TNS Gallup 2006).

The municipal websites are used by about 70 percent of those having access to the Internet, representing 55 percent of the total population in the four municipalities. Fewer than this have read the political contents of the website. The proportions of the public having used the different contents of the municipal websites are indicated in Figure 2, alongside the proportions of the population using other information sources. ${ }^{8}$

\section{Figure 2. The Proportions of the Population Having Used Different Information Sources}

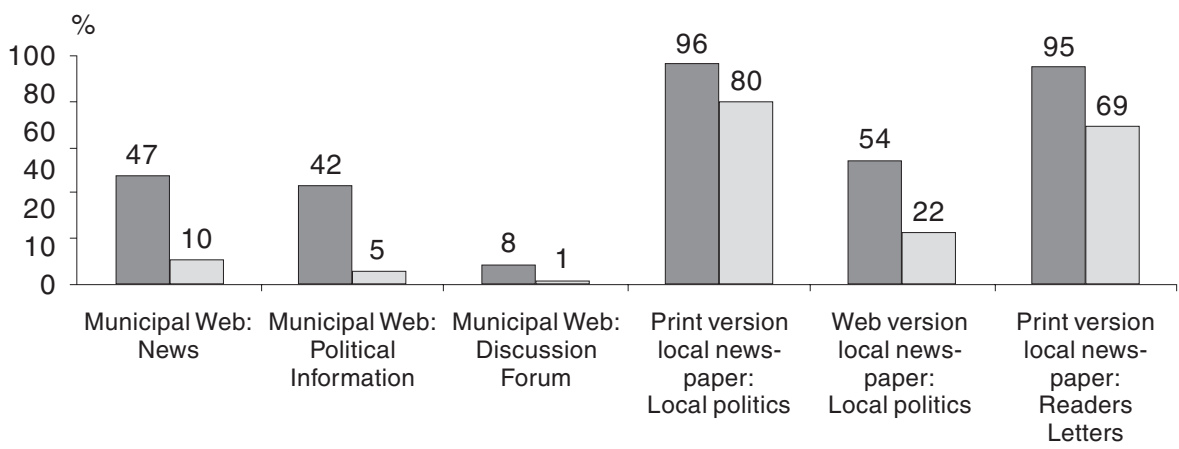

Infrequent Users $\square$ Regular Weekly Users

As Figure 2 indicates, the municipal websites are less used and thus less visible to the public than either the printed or the net based version of the local newspaper. Even so, the websites are far from invisible, as almost half of the total population have used the websites to read the news or have searched for political information. Discussions on the website are also less visible to citizens than are political discussions and readers' letters in the newspaper. Only eight percent of the survey sample in the four municipalities, state having visited the municipal forum. ${ }^{9}$ The number having followed discussions in the readers' letters in the newspaper is substantially higher. 
The survey shows that only a small proportion of the citizens use the municipal website regularly as source of political information. The identity of these individuals is, however, not without significance. Do they represent a cross section of the population or do they differ from other citizens in any essential way? Earlier studies have shown that digital political activity is most common among young people and those already politically active (Saglie \& Vabo 2005), a tendency confirmed in this study. The differences between age groups and between the politically active and inactive remain significant when analyzed by a linear regression, controlling for education, income and gender. The results of the regression are displayed in Table $1 .{ }^{10}$

Table 1. Use of the Political Content on the Municipal Website (Linear regression analysis - Standardized coefficients)

$\begin{array}{lcc} & \begin{array}{c}\text { How often do you read } \\ \text { news on the municipal } \\ \text { website? }\end{array} & \begin{array}{l}\text { How often do you search } \\ \text { for political information } \\ \text { on the municipal website? }\end{array} \\ \text { Beta } & \text { Beta }\end{array}$

Even though age is correlated with political activity in digital arenas, the correlation is smaller than one might expect. One reason for this is that the correlation that exists is not quite linear. Use of the political content of the municipal website is fairly constant across the age groups up to the age of 60, then dropping with increasing age. The use of the Internet for other purposes follows the same pattern, indicating increasing incorporation of the Internet in everyday life, across age groups. The most important factor for predicting the use of the political contents on the municipal website is the degree of political activity in non-digital arenas. Political activity was in this case measured by an activity index consisting of eight variables. The relatively high and persistent effect of this variable when controlled for socio-demographic characteristics, tells us that the political content on the municipal websites is most visible to those already politically active. ${ }^{11}$ This indicates that the politically active use the opportunity to be informed by alternative sources and are potentially exposed to different perspectives, whereas the politically inactive make use of this opportunity to a lesser extent.

As could have been expected, journalists and politicians use the websites more frequently than the rest of the population. Most politicians (about 85 percent in the case municipalities) visit the website regularly. ${ }^{12}$ The journalists responsible for covering local politics in the newspapers all reported visiting the municipal website frequently, most of them daily, regularly checking the post journals, meeting agendas and documents related to forthcoming issues. Most of them also routinely read the news published on the website, but they rarely or never checked the discussion forums. 
The website may be considered visible and important even though not very much used. In the survey the citizens were asked to evaluate the importance of different sources of information on local politics in their own municipality. The results are displayed in Figure $3 .{ }^{13}$

Figure 3. The Relative Importance of News Sources for Local Politics

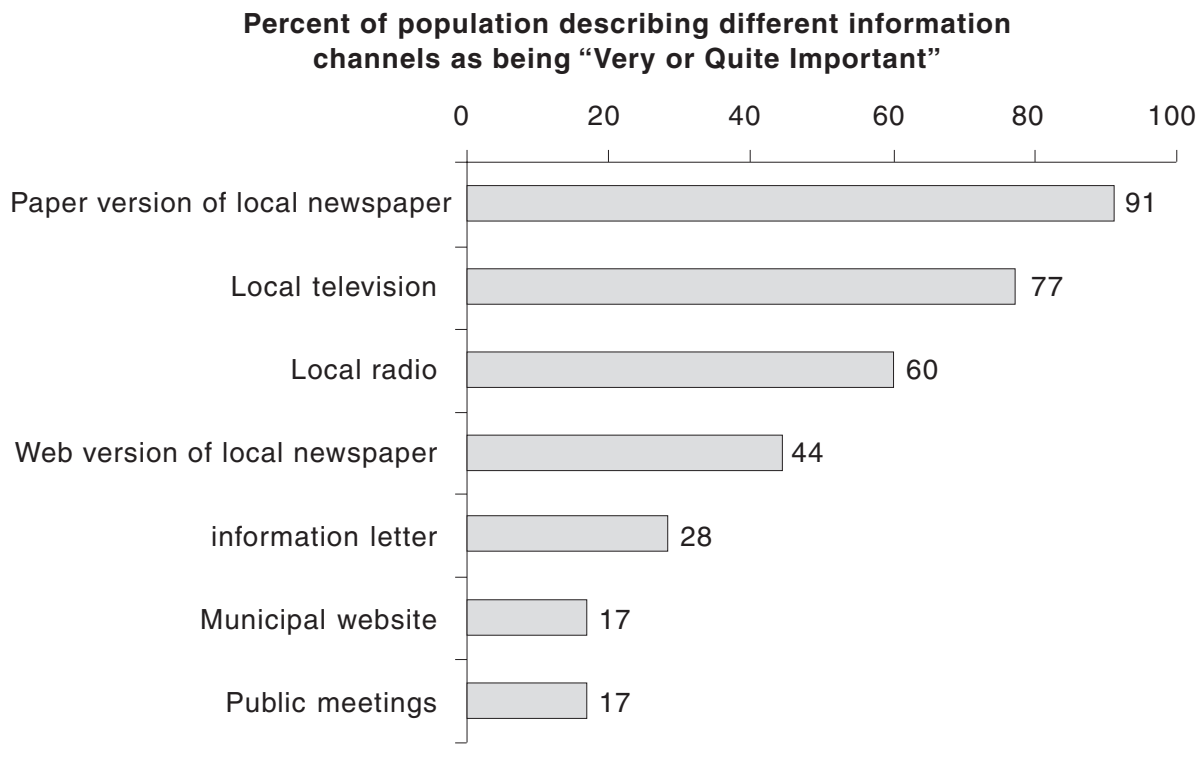

$(N=1222)$

As Figure 3 indicates few citizens consider the municipal website as important for information on local politics compared to the importance attributed to other information channels and especially the traditional local media. This corresponds with the low use of the municipal website, as referred to above. There are however significant differences between the municipalities concerning the assessed importance of the municipal website, ranging from the highest in Drammen, where 25 per cent of the citizen state that the website is an important source of information on local politics, to the lowest in Stavanger where only 11 per cent consider the website important. That the municipal websites are important to a small, but still significant number of citizens, is surprising, when considering the infrequent updates. It is also interesting to notice that a proportion of the infrequent users of the municipal websites consider them important. This may indicate that some citizens feel they can get important, alternative information from the websites on certain occasions, even though they do not use them regularly to keep up to date on local politics.

There may be several reasons why the municipal websites are less used and thereby less visible to the public than other channels for political communication. The most obvious explanation, pointed out by many of the interviewed journalists, is habit. People are used to reading about local news and local politics in the newspaper, and until they get a good reason to change, they will stay with this media. Another likely explanation why the websites are not as much used is the readability of the contents - a rea- 
son forwarded by both journalists and the information departments of the municipalities. The newspaper is composed by journalists knowing how to write good stories. The information department in the municipality neither have the resources nor the competencies to make the website tempting and readable. Neither, claim many of them, do they want to make it too tempting, because websites must seem official, sober and neutral. People may also expect to find information and not news on the municipal website, due to the fact that it represents an official institution. When people use the media they do it both to be informed and to be entertained whereas they probably turn to the municipal website mainly when they have a specific purpose for doing so. If people rely on media bringing them the most important news in a more entertaining wrapping, they have little reason to look up the news on the municipal website. A local politician from Stavanger underscores this point: "Few people have the municipal website as their favourite [...] People don't visit this website to have a good time [...] they use it in a purposeful manner" (Interview 1). ${ }^{14}$

The frequency of updates may also explain why the websites are considered less important than the traditional media. The most updated municipal website, - Drammen - which is also the one considered most important by the citizens, was updated less than twice a day. Comparably, the local Drammen newspaper publishes approximately a hundred new news items each day. Infrequent updates may also explain why so few visit the municipal discussion forums. On the discussion forums on the three websites that offered this opportunity, the average interval between each new posting was one month. In contrast, between five and twenty reader's letters were published in the local newspapers every day.

\section{Agenda Influence}

If information or arguments originating in the municipal website are visibly transferred to another arena in the public sphere, this indicates that the website is connected to the wider network of interrelated public sphere segments and that the content is likely to be received by a wider audience and has a certain influence on the public debate. Two indicators are proposed to assess the influence that the municipal website has on the agenda of the media; politicians and journalists' evaluation of the agenda setting function of the municipal website and the degree of spill-over from the municipal websites to the press, which is tentatively established through a content analysis. I have chosen to look at the influence that the municipal websites have on the agenda of the printed press, because the press is the information source that is considered most important by the public.

But first, as information is rarely neutral, a short discussion of whose agenda is appearing on the municipal website is needed. The different contents of the website have different sources. The meeting agendas and minutes represent the agenda of the politicians, whereas the selected and framed presentation of the news reflects the agenda of those responsible for the website. Employees in the information department as well as journalists and politicians were interviewed regarding whose agenda was represented in the news items on the website. Most of them quoted the administration, and especially the information department. Some politicians, belonging to both the majority and to the opposition, believed that the municipal website was under the control of the political majority in the municipal council, and as the majority was responsible for political decisions, they wanted to promote the positive side of the politics conducted whilst hid- 
ing the deficiencies. Also many journalists believed the municipality presented a slanted picture of certain issues. Other journalists believed that the municipality was an official institution, aiming at neutrality, and that the contents of the websites represented mere facts. A definite answer as to whose agenda is appearing on the website can not be given, but as will be demonstrated, the use of the website was affected by the way the contents were perceived - as neutral or strategic.

The municipal information departments in the different municipalities all assess their role as agenda setters as quite important, stating that an important function of the municipal web is to hand cases to the press and thereby contribute to the political agenda. They do this by publishing articles on the website, hoping the media will pick up the story, as reflected in the citation of this information department employee: "The journalists are lazy, they cut and paste [...] I won't deny we use this consciously to make them cover things" (Interview 3 ). The municipalities also use the websites strategically to exhaust the newsworthiness of a case. If a case is considered bad for the image of the municipality, the information department may publish a small notice on the website and lessen the chances of the newspaper grabbing it. "Then the media doesn't bother, and we prevent them making a big story" (Interview 4). The information departments also make assessments in the other direction, not writing about certain cases: "We leave the good and positive things to the press. If we cover it, they may not" (Interview 5).

Furthermore, the information departments strategically use the websites to present a certain picture of a case. Their aim is to correct the picture drawn by the media which they often find biased and unfairly negative. "We consciously use the website to compensate negative publicity in the sensation seeking media" (Interview 3 ). This, they try to accomplish both by presenting alternative and more positive information on a subject matter, and by being proactive. The information department in Drammen reported publishing positive news on the situation of care for the elderly in the municipality, after it had been massively criticized in the newspaper. However, they realized that it was difficult to restore the picture after the media had ruined it and were set on becoming more proactive, publishing news early with a positive angle: "The newspaper always presents a slanted picture, and when they do, the damage has already happened [...] We have to be one step ahead, to bring the correct and neutral picture before the press get their hands on it" (Interview 2). Another aim was to present a positive picture of the municipality as a place to live. The website was characterized as the official site in relation to the world at large and they wanted to give people both outside and inside the municipality a positive impression of the local community: "We try to set the municipality on the map, sell it" (Interview 2).

The interviewed journalists not surprisingly judged the position of the municipal websites in agenda setting as less important than did the people in the information department of the municipality. The journalists discerned between being a news deliverer and an information provider. Information providers were considered as sources that influenced the agenda, only to a modest extent. News providers, (as the journalists regarded themselves), had influence on the agenda, deciding what was presented as important and of current interest. All the journalists assessed the municipal website as an important channel of information and they reported regularly using information found in the mail journals, meeting agendas and other political documents. Most journalists did not however think of this as the municipal website setting the agenda, because they considered the information only to represent pure facts on what was happening in the 
council or in the municipality, as the journalist from Stavanger stated: "They bring information, we make news" (Interview 7). The aspect that had changed with the introduction of the municipal websites was, according to the journalists, that they could get hold of the cases and relevant documents more easily and at an earlier stage. The web pages made "digging journalism" much easier. The cases made available through the web would probably have been news anyway, but at a later stage.

Some of the journalists admitted however that the municipal web occasionally served as a news deliverer, meaning the municipality had made a story of something by publishing an article about it, and the journalist reproduced the story in the newspaper. Some journalists reported that they sometimes even copied the news: "If the deadline is approaching, I'm at the editorial desk and I'm desperate, I cut and paste from the municipal web" (Interview 9). They reported nevertheless mostly writing their own version of what they found on the web page. The explanation for not copying was the form of the texts on the municipal website: "It is necessary to contextualize it and find an angle, [...] to make it more readable, less dry, to make it news" (Interview 10). Other journalists denied that this happened. As one journalist in Troms $\varnothing$ stated: "They don't deliver news, that is nonsense [...] They want to deliver news, and they want us to cite them, but we never do" (Interview 8). In general, journalists were sceptical towards carefully written texts coming from the municipality. Journalists in Drammen differed however from the journalists in the other municipalities, attributing a more pronounced agenda setting function to the municipal website. It seems this website was better integrated in the public debate.

Whether the journalists' distinction between a news provider and an information channel is adequate is open to discussion as the selection of facts available on the municipal website is likely to influence the way a story is presented in the newspaper. Furthermore, as the journalists also admit, facts are rarely neutral, so the framing of facts could also possibly influence the way a case is presented in the media. Also the timing of the release of documents can be of importance for agenda setting.

The journalists reported that they rarely quoted the source when using contents from the municipal website. One of the stated reasons for doing so was that the content of the municipal website represented "mere facts" and not arguments, and the journalists did not feel they had to quote the source to legitimise the content. They did however, as mentioned above, assess some of the contents as less neutral, but gave no clear explanation as to why they did not refer to the source in these cases. Another reason given for not quoting was that the municipal websites were not acknowledged as media channels, but perceived as sources. The journalists reported being careful to quote other media as sources.

Concerning the potential for the municipality to frame cases and present a chosen angle, some journalists thought the website might, at least potentially, succeed in this, as reflected in the statement from this journalist: "The municipal web is the municipality's own channel where they can present their own picture of the municipality and politics. [It] may function as a corrective to us" (Interview 10). Nonetheless, journalists doubt that many people read the website, a doubt that is confirmed by the survey, and they consequently find it unlikely that the municipal web competes with the newspaper when it comes to framing cases. The press is critical of the picture that the municipality draws and looks at it as part of their assignment to reveal any hidden agenda that the authorities might have: "The municipality provides their view on things. Our mission is to tear their information apart and look at it with a critical view" (Interview 6). 
The politicians in the four municipalities considered the municipal website of little importance to the public debate. As a politician from Stavanger put it: "The municipal web may be situated in the public sphere, but at the very back, and sparsely illuminated" (Interview 1). When politicians wanted to communicate with the public or to take part in the public debate, they did not use the municipal website, but the media, and especially the printed version of the local newspaper.

The spill-over of contents reported by both the municipal information departments and the journalists was hard to establish through content analysis, partly because, as they had warned, the journalists did not quote the source when referring to the municipal websites. Some incidents of spill-over were nevertheless identified in the three week period of the content analysis - most of them in Drammen. In most cases spill-over occurred as small notes on practical information, like the schedule of the mayor or the dates of council meetings. These were the only examples of direct copying that were found. Another type of spill-over which was identified was articles referring to background documents published on the website prior to a council meeting. The journalists had clearly found the background documents on the municipal web as they were not available elsewhere. They made their own stories related to the documents, referring, for example, to 'a report presented to the municipal council', but did not quote the website as source. Yet another type of spill-over of which three occurrences were identified, were articles building on news published on the front page of the municipal website. One of these treated the satisfaction of the users of care for the elderly in Drammen, previously mentioned by the Drammen information department. A survey among the users of the care for the elderly in the municipality had showed that most users were content with the services they received. The news piece from the municipal web had been slightly rewritten and published in the newspaper without any critical comments. Again the source was not quoted. News published on the municipal websites as responses to debates in the newspapers were also found. There was a controversy, again in Drammen, over a proposal from the mayor to include the neighbouring municipality in Drammen. After a week of attacks by the media, the information department published an interview with the mayor on the municipal website where he was allowed to state his opinion on the matter and defend himself. When the discussion continued in the newspaper, this interview was however not referred to by the other participants in the debate. It was not until the mayor wrote a contribution in the newspaper that the arguments, previously occurring in the website article, were included in the debate and cited by the journalists. This may indicate that journalists do not acknowledge what is published at the website as belonging to the public debate. Journalists also state being more sceptical to the content on the websites in controversial cases, when the municipality is regarded as having a role in a conflict.

To summarize, both interviews and content analysis indicate that the municipal websites to a certain degree influence the political agenda of the press. The information department in the municipalities use the websites strategically to feed the press stories they want covered, and according to the information department they succeed. Proof of such spill-over is also found in the content analysis. To a lesser extent they succeed in framing and presenting a certain picture of a case to the press. Many journalists perceive the content of the website as being strategic and use it with caution. Still, some examples of journalists copying biased stories from the municipal websites are found.

The website of Drammen stands out as the most agenda influencing website among the four: it is considered more important by the citizens and is more referred to by the 
journalists and is thereby having greater impact on the public agenda. A reason for this may be that their website is better developed than those of the other municipalities. Drammen has more resources in the information department, mainly due to a mayor actively favouring the website. More new news items are published every day and the articles are more readable and more story-like than in the other websites. Also, in Drammen, political documents needed by the politicians are only available through the website, and the press can consequently count on getting the same documents as the politicians through the website.

\section{Conclusion}

The evaluation of the visibility and agenda influence of the municipal websites indicates that the websites are both connected to and have influence on the wider public debate. The position that the websites hold in the public debate is however not a prominent one. They are not much used and consequently not particularly visible to the citizens, compared to other local media. Still, about one of six citizens considers the municipal website as an important source of information on local politics, and the content published on the website widens the scope of information these citizens hold. Keeping in mind that these are the most politically active citizens, the influence on the public debate is presumably greater than the proportion using them implies. The most important role of the municipal websites at the present is however as a source, feeding the traditional media with facts and issues. Even if directly visible only to a few, some of the contents of the municipal websites are indirectly made visible to many more citizens through the media. The fact that the journalists refer to the municipal websites leads to a spill-over of content from the municipal websites to the press, which connects the contents of the websites to the wider public debate. Through this spill-over the websites does to a certain extent influence both the agenda and the framing of issues in the media.

A theoretical advantage of the Internet is that it may contribute to a more pluralistic public debate by facilitating the information flow and by allowing, in principle, every citizen to broadcast their opinions. However, if different segments of the audience are exposed to different and unconnected information, the debate will not be more pluralistic, but more fragmented. Non-coherency of the different arenas of political communication indicates a fragmentation of the public debate, whereas the interconnectedness of different segments of the public sphere indicates an enlarged and pluralised public debate.

As illustrated by the analysis, the municipal websites can be characterized as a part of the wider public debate in local society. The municipal websites publish contents with a different angle, a different framing and other details than the media. These contents reach outside their initial setting, both because they are directly visible to a certain proportion of the citizens and because they are referred to in the media. This indicates that the municipal websites are interfering with and affecting the political communication taking place in other arenas, ensuring different voices are heard and thereby contributing to the pluralism of the public debate. The printed press, being the main supplier of political news and arguments reaching almost the totality of the public, ensures that the contents of the municipal websites enter into and become part of the public discourse. The fact that the municipal websites function as an information source to the press counteracts a fragmentation of the public debate. In this way, the population is still exposed to approximately the same set of political arguments, indicating there is one coherent public debate. 
However, it is questionable whether the function as a strategic source of information, made possible mainly through the news items, adds to the pluralism of the debate. As indicated, news items are selected and framed stories of the activities in the municipality, allowing the municipality to compete with the media in defining reality. The municipality can, via the website, present an alternative version of what is happening, free from the filtering and framing of the media, giving the municipality better control over its public image and a new and possibly more effective way to direct information to the newspapers. The information departments strategically use the website to feed the media with stories they want covered, to minimise the newsworthiness of a case they do not want covered and to bring an alternative picture of the activities of the municipality, correcting or modifying the picture presented by the media. Such strategic information, with the aim of defining the reality and excluding criticism, does not necessarily contribute to the pluralism of the debate as the website does not present an alternative or critical angle, but on the contrary takes possession of the debate, making it just as uniform and undifferentiated as it would have been without this contribution.

The added democratic value of the municipal websites can thus be questioned. The municipal websites can contribute to a more informed and pluralistic debate, but do so only to a modest extent, as they are not extensively used as an alternative source of information and their function as a source partly contributes to the uniformity of the debate.

The websites offer the municipalities a more permanent public display for their citizens than other pre-Internet information channels such as information folders, advertisements in the newspaper and public meetings. At the present moment it looks as if the municipal websites are searching for an identity, being a hybrid wanting simultaneously to compete with the newspapers in defining reality, to be a strategic information source and to bring neutral and factual information to the public. The evaluation of the position of the municipal websites in the public debate provided here is no more than a snapshot. The municipal website is a relatively new creation and what role it will play in the local public debate in the future will depend on how it is used by the public and the media and how it is developed. Its position may also depend on whatever interpretations of its role that gains weight. If the strategic face of the website becomes too visible people may stop trusting it.

\section{Notes}

1. The study is part of the project "ICT and local democracy" financed by the Research Council of Norway through the program: "Communication, ICT and Media".

2. Compared to results from the representative national survey on the local election from 2003, with a response rate of 69 (Saglie \& Bjørklund 2005: 329-332), the proportions of people stating they have participated in different political activities in the last four years do for most activities not differ substantially. The number of people stating they have taken part in local campaigns, contacted local politicians or are members of a political party are nearly identical in the two surveys. The number of people stating they have participated in the municipal election is however higher in this sample than in the overall population.

3. Drammen has, since the data was collected, created a discussion forum while Troms $\varnothing$ has removed theirs.

4. The questions posed was: 1) "Do you have access to the Internet in one or more of the following places: Home, at work, elsewhere". 2) "Approximately how often do you use the Internet: Daily, weekly, Monthly, More rare, Never".

5. In October 2005,83 per cent of the total Norwegian population had access to the Internet, 76 per cent use it monthly and 73 per cent weekly or more often. 
6. The relationship between access to the Internet and age, income and education remains significant when included in a binary logistic regression. The relation between use of Internet and the same variables remains significant when included in a linear regression.

7. The question posed was: "Approximately how often do you read the paper version of the local newspaper in your municipality? Daily, Weekly, Monthly, More rare, Never"

8. The questions posed were: "Approximately how often do you 1) Read the news on the municipal website? 2) Search for political information on the municipal website? 3) Visit the discussion forum on the municipal website? 4) Read about local politics in the printed version of the local newspaper? 5) Read about local politics in the web version of the local newspaper? Daily, Weekly, Monthly, More rare, Never".

9. Drammen was omitted from this analysis because they did not have a discussion forum on their website.

10. Age is a continuous variable. Education and income are ordinal variables, where as gender is a dummy, coded man=0, woman $=1$. Political activity is a continuous index ranging from 0 to 8 , where low value indicates low political activity. The variables in the index was based on the following yes/ no- questions: Have you during the last four years... 1) voted in the municipal election, 2) participated in a protest meeting or demonstration concerning local issues, 3) contacted local politicians about a local issue, 4) contacted the municipal administration about a local issue, 5) contacted the media about a local issue, 6) signed a petition about a local issue, 7) called a radio or television program about a local issue, 8) written a letter to the editor.

11. As political activity is a control variable in the regression model, comparing the politically active to the politically inactive, the bias of the population sample is not likely to affect the results of the regression.

12. The percentage represents the proportion of politicians stating that they use the website "Very or Quite often".

13. The questions posed were: "How important do you consider the following sources of information on local politics in your municipality: The paper version of the local newspaper, Local television, Local radio, Web version of local newspaper, Information letters from the municipality, Municipal websites, Public meetings? Very important, Quite important, Neither important nor unimportant, Rather unimportant, Not important at all".

14. All citations are translated from Norwegian to English by the author.

\section{References}

Dahlberg, Lincon (2004) 'Net-Public Sphere Research: Beyond the First Phase', The Public 11(1): 27-44.

Eriksen, Erik O. \& Jarle Weigård (2003) Understanding Habermas. Communicative Action and Deliberative Democracy. London: Continuum.

Fraser, Nancy (1992) 'Rethinking the Public Sphere: A Contribution to the Critique of Actually Existing Democracy', in Craig Calhoun (ed.) Habermas and the Public Sphere. London: MIT Press.

Fuller, Jill E. (2004) 'Equality in Cyberdemocracy? Gauging Gender Gaps in On-Line Civic Participation', Social Science Quarterly 85(4): 938-957.

Fung, Anthony (2002) 'One City, Two Systems: Democracy in an Electronic Chat Room in Hong Kong', Javnost, The Public 9(2): 77-94.

Groves, Robert M., Stanley Presser \& Sarah Dipko (2004) 'The Role of Topic Interest in Survey Participation Decisions', Public Opinion Quarterly, 68(1): 2-31.

Habermas, Jürgen (1971) Borgerlig offentlighet-dens framvekst og forfall. [The Structural Transformation of the Public Sphere]. Oslo: Gyldendal.

Habermas, Jürgen (1996) Between Facts and Norms. Cambridge: Polity Press.

Hoff, Jens \& Kresten Storgaard (eds) (2005) Informasionsteknologi og demokratisk innovation borgerdeltakelse, politisk kommunikation og offentlig styring [Information technology and democratic innovation]. København: Forlaget Samfundslitteratur.

Janssen, Davy \& Raphaël Kies (2005) 'Online Forums and Deliberative Democracy', Acta Politica (40): 317-335.

Jensen, Jakob Linaa (2003) 'Public Spheres on the Internet: Anarchic or Government-Sponsored - A Comparison'. Scandinavian Political Studies 26(4): 349-374.

Liestø1, Gunnar \& Terje Rasmussen (2003) Digitale medier: En innføring [Digital Media: An Introduction]. Oslo: Universitetsforlaget.

Kjeldsen, Jens E. (1998) 'Duellanter, følelser og urokkelige standpunkter - Fjernsynsdebatten som retorisk genre [Duelists, feelings and firm beliefs - Television debate as rethoric genre] in Børdahl, Ove, et al., Retorikkens omegn. Retorisk årbok 1998. Bergen: Senter for europeiske kulturstudier. 
Kosicki, Gerald M. (1993) 'Problems and Opportunities in Agenda-Setting Research', Journal of Communication 43(2): 100-127.

March, James G. \& Johan P. Olsen (1989) Rediscovering Institutions: The Organizational Basis of Politics. New York: Free Press.

Mouffe, Chantal (1999) 'Deliberative Democracy or Agonistic Pluralism?' Social Research 66(3): 745-758.

Norris, Pippa (2001) Digital Divide: Civic Engagement, Information Poverty and the Internet Worldwide. Cambridge: Cambridge University Press.

Nygren, Gunnar (2005) Skilda medievärldar. Lokal offentlighet och lokala medier $i$ Stockholm [Separate media worlds. Local public sphere and local media in Stockholm]. Stockholm: Symposion.

Papacharissi, Zizi (2002) 'The Virtual Sphere. The Internet as a Public Sphere', New Media \& Society 4(1): 9-27.

Papacharissi, Zizi (2004) 'Democracy Online: Civility, Politeness, and the Democratic Potential of Online Political Discussion Groups', New Media \& Society 6(2): 259-283.

Polat, Rabia Karakaya (2005) 'The Internet and Political Participation. Exploring the Explanatory Links', European Journal of Communication, 29(4): 435-459. London: Sage Publications.

Poster, Mark (1997) 'Cyberdemocracy: Internet and the Public Sphere', in D. Porter (ed.) Internet Culture. New York: Routledge.

Saglie, Jo \& Signy Vabo (2005) Elektronisk politisk deltakelse - en aktivitet for de få? [Electronic political participation - an activity for the few?'], in J. Saglie \& T. Bjørklund (eds) Lokalvalg og lokalt folkestyre. Oslo: Gyldendal Akademisk.

Statistics Norway (2006) http://www.ssb.no/emner/10/03/ikt, accessed January $10^{\text {th }} 2006$.

Statistics Norway, Research and Analysis (2006) http://www.ssb.no/forskning.

Thompson, John B. (1995) The Media and Modernity. A Social Theory of the Media. London: Polity Press. TNS Gallup (2006) http://www.tns-gallup.no, accessed January $10^{\text {th }} 2006$.

Tobiassen, Mette (2005) 'Digitale skillelinjer [Digital divides]', in Lars Torpe et. al: Demokrati på nettet. Aalborg: Aalborg Universitetsforlag.

Torpe, Lars (2005) 'Internet, demokrati og politisk offentlighed [Internet, democracy and the political public sphere]', in Torpe, Lars, Jeppe Agger Nielsen \& Jens Ulrich: Demokrati på nettet. Aalborg Universitetsforlag.

Ulrich, Jens (2005) 'Den demokratiske samtale på nettet - en kvalitativ analyse af debatten på hals.dk' [The democratic conversation on the net - a qualitative analysis of the debate on hals.dk], in Torpe, Lars, Jeppe Agger Nielsen \& Jens Ulrich: Demokrati på nettet. Aalborg Universitetsforlag.

\section{Interviews with the Author}

Interview 1 - Stavanger politician interviewed on 01.04. 2005

Interview 2 - Drammen Municipal Information Department interviewed on 11.10. 2004

Interview 3 - Førde Municipal Information Department interviewed on 19.10. 2005

Interview 4 - Stavanger Municipal Information Department interviewed on 20.03. 2004

Interview 5-Troms $\emptyset$ Municipal Information Department interviewed on 8.12. 2004

Interview 6 - Førde journalist interviewed on 19.11. 2005

Interview 7 - Stavanger journalist interviewed on 01.04. 2005

Interview 8 - Troms $\varnothing$ journalist interviewed on 8.12. 2004

Interview 9 - Drammen journalist interviewed on 3.11. 2004

Interview 10 - Drammen journalist interviewed on 8.11. 2004

MARTE WINSVOLD, Cand.Polit., Researcher, Norwegian Institute for Urban and Regional Research, P.O. Box 44 Blindern, NO-0313 Oslo, marte.winsvold@ nibr.no 